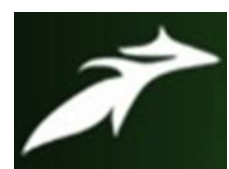

V. S. Hooda et al, International Journal of Advances in Agricultural Science and Technology,

Vol.7 Issue.12, December-2020, pg. 98-103

ISSN: 2348-1358

Impact Factor: 6.057

NAAS Rating: 3.77

\title{
Integrated Weed Management in Mustard (Brassica juncea L.)
}

\author{
V. S. Hooda ${ }^{1}$; Satyajeet $^{2}$; Ashok Yadav ${ }^{3}$ \\ ${ }^{1}$ Assistant Scientist, Department of Agronomy, CCSHAU, Hisar, Haryana (India); \\ ${ }^{2}$ Assitant Scientist (Agronomy), RRS, Bawal (CCSHAU), Haryana (India); \\ ${ }^{3}$ Professor, Department of Agronomy, CCSHAU, Hisar, Haryana (India); \\ *Corresponding author (Email- vshooda79@ gmail.com) \\ DOI: 10.47856/ijaast.2020.v07i12.013
}

\begin{abstract}
To study the efficacy of different herbicides integrating with hand weeding in mustard, a field investigation was planned during rabi season of 2011-12 and 2012-13 at Research Farm of Department of Agronomy CCS Haryana Agricultural University, Hisar. Various treatments included were trifluralin $750 \mathrm{~g} / \mathrm{ha}$ PPI (pre plant incorporation), trifluralin $750 \mathrm{~g} / \mathrm{ha}$ PPI + $1 \mathrm{HW}$ (hand weeding) 45 DAS (days after sowing), trifluralin $1000 \mathrm{~g} / \mathrm{ha}$ PPI, trifluralin $1250 \mathrm{~g} / \mathrm{ha}$ PPI, pendimethalin $750 \mathrm{~g} / \mathrm{ha}$ PPI, pendimethalin $750 \mathrm{~g} / \mathrm{ha} \mathrm{PPI}+1 \mathrm{HW}$ 45 DAS, pendimethalin $1000 \mathrm{~g} / \mathrm{ha}$ PPI, pendimethalin $1250 \mathrm{~g} / \mathrm{ha}$ PPI, pendimethalin $750 \mathrm{~g} / \mathrm{ha}$ PRE (pre emergence), pendimethalin 750 g/ha PRE + 1 HW 45 DAS, pendimethalin 1000 g/ha PRE, pendimethalin $1250 \mathrm{~g} / \mathrm{ha}$ PRE, 1HW 30 DAS, 2 HW 30 and 60 DAS, weedy and weed free check. The seed yield and various yield attributes of irrigated mustard were increased when trifluralin (PPI) or pendimethalin (PPI \& PRE), each at $750 \mathrm{~g} / \mathrm{ha}$ integrated with $1 \mathrm{HW}$ at $45 \mathrm{DAS}$, and these were comparable to the treatment of $2 \mathrm{HW}$ (30 and $60 \mathrm{DAS}$ ) and also to the weed free conditions. In mustard, the PPI application of pendimethalin was superior over PRE application, however there was no significant differences in yield. Weeds allowed to grow through the crop season reduced the seed yield of mustard to the extent of 30.4 and $33.9 \%$ during 2011-12 and 2012-13, respectively.
\end{abstract}

Keywords: Mustard, weeds, pendimethalin, trifluralin, hand weeding

\section{Introduction:}

India is one of the largest oilseeds producing country and oilseeds are the second largest agricultural commodity after cereals in India. Among oilseeds, Raya/Indian mustard (Brassica juncea L.) occupies a prominent crop and ranks second after groundnut in area and production, contributing about $23 \%$ of the total oilseed production. It is grown in 5.98 million hectare are in India, predominantly in states of Rajasthan, UP, Haryana, Madhya Pradesh and Gujarat both under irrigated and rainfed conditions with a production of $8.43 \mathrm{~m}$ tonnes (Anonymous, 2019). Though the average yield of mustard in Haryana $(1596 \mathrm{~kg} / \mathrm{ha})$ is highest in the country, it is far below the average yield of mustard in Europian Union, Canada, Ukraine and Belarus. It is even below the world average yield of $2070 \mathrm{~kg} / \mathrm{ha}$. There is wide gap between the genetic potential of the released varieties and the actual average yield. Among various environmental and other constraints responsible for low productivity, 


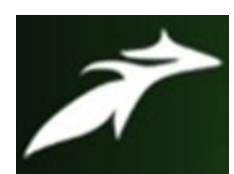

V. S. Hooda et al, International Journal of Advances in Agricultural Science and Technology, Vol.7 Issue.12, December-2020, pg. 98-103

ISSN: 2348-1358

Impact Factor: 6.057

NAAS Rating: 3.77

management of weeds is of paramount importance. Crop is severely infested by both grassy and broadleaf weeds, particularly under irrigated conditions. Yield losses due to crop-weed competition in rapeseed and mustard have been estimated to the tune of 10-58\% (Banga and Yadav, 2001 and Malik et al., 2012) depending upon the type, intensity and duration of competition. Punia et al. (2006) reported that presence of weeds throughout growing period resulted in 36-42 per cent reduction in seed yield of mustard. Under All India Coordinated Project on Rapeseed-Mustard, from various locations $18.1 \%$ (Ludhiana) to $41.7 \%$ (Varanasi) mustard yield loss has been reported (Anonymous, 2011). Chauhan et al. (2005) reported that weed competition in mustard is more serious in early stage because crop growth during winter (rabi) season remains slow during the first 4-6 weeks after sowing and during later stage it grows vigorously and suppressing effect on weeds. With the increasing demand for food, cost reduction and high intensive management and increasing wages and scarcity of labour, the use of pesticide, particularly herbicides, has been increasing in modern

agriculture. Traditional methods of weeding by khurpa or kasola is still the most common practice of weed control in mustard fields but non-availability and high wages of labor make it difficult and costly. We need some suitable method of weed management in mustard either with herbicide alone or in integration with mechanical/manual weeding for higher crop yield (Malik et al., 2012). Keeping it in view, present investigation was planned to study the efficacy of different herbicides integrating with hand weeding in mustard.

\section{Methodology:}

A field experiment was conducted during the rabi seasons of 2011-12 and 2012-13 at Research Farm of Department of Agronomy, CCS Haryana Agricultural University, Hisar to find out the suitable method of weed management in mustard. The soil of the experimental field was sandy loam in texture, low in available $\mathrm{N}$, medium in available $\mathrm{P}_{2} \mathrm{O}_{5}$ and high in $\mathrm{K}_{2} \mathrm{O}$ with slightly alkaline in reaction $(\mathrm{pH} 8.1)$. Raya/mustard variety $\mathrm{RH} 30$ was sown by drill at $30 \mathrm{~cm}$ row to row spacing on $19^{\text {th }}$ October and $22^{\text {nd }}$ October during 2011-12 and 201213, respectively. The experiment consisting of various treatments viz. trifluralin $750 \mathrm{~g} / \mathrm{ha}$ PPI (pre plant incorporation), trifluralin $750 \mathrm{~g} / \mathrm{ha}$ PPI $+1 \mathrm{HW}$ (hand weeding) $45 \mathrm{DAS}$ (days after sowing), trifluralin $1000 \mathrm{~g} / \mathrm{ha}$ PPI, trifluralin $1250 \mathrm{~g} / \mathrm{ha}$ PPI, pendimethalin $750 \mathrm{~g} / \mathrm{ha} \mathrm{PPI}$, pendimethalin $750 \mathrm{~g} / \mathrm{ha}$ PPI + $1 \mathrm{HW} 45 \mathrm{DAS}$, pendimethalin $1000 \mathrm{~g} / \mathrm{ha} \mathrm{PPI}$, pendimethalin $1250 \mathrm{~g} / \mathrm{ha}$ PPI, pendimethalin $750 \mathrm{~g} / \mathrm{ha}$ PRE (pre emergence), pendimethalin $750 \mathrm{~g} / \mathrm{ha} \mathrm{PRE}+$ $1 \mathrm{HW} 45$ DAS, pendimethalin $1000 \mathrm{~g} / \mathrm{ha}$ PRE, pendimethalin $1250 \mathrm{~g} / \mathrm{ha}$ PRE, 1HW 30 DAS, 2 HW 30 and 60 DAS, weedy and weed free check was laid out in randomized block design replicated thrice. The herbicides were applied by using knapsack sprayer fitted with flat fan nozzle in a spray volume of 500 liters/ha. The crop was raised with all the package of practice recommended by the state university. The data on density of individual weeds and dry weight of total weeds was recorded at 70 DAS by randomly placing two quadrates $(0.5 \times 0.5 \mathrm{~m})$ per 


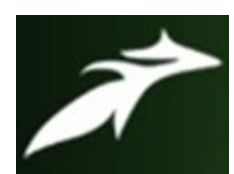

V. S. Hooda et al, International Journal of Advances in Agricultural Science and Technology, Vol.7 Issue.12, December-2020, pg. 98-103

ISSN: 2348-1358

Impact Factor: 6.057

NAAS Rating: 3.77

plot. The dry weight of weeds was recorded by keeping the weeds in oven at $70{ }^{0} \mathrm{C}$ till constant weight was achieved. The seed yield of crop along with other yield attributes were recorded at harvest to draw inference of results.

\section{Results and Discussion:}

\section{Effects on Weeds}

The experimental field of mustard was infested with various weeds like bathu (Chenopodium album), hirankhuri (Convolvulus arvensis), metha (Melilotus indicus) and kandai (Cirsium arvense) during the study. The density and dry weight of weeds reduced with the corresponding increase in the dose of each herbicide, however, such reactions were more pronounced when trifluralin (PPI) and pendimethalin (PRE), each at $750 \mathrm{~g} / \mathrm{ha}$ were integrated with $1 \mathrm{HW}$ at 45 DAS (Tables 1). Integration of $1 \mathrm{HW}$ at 45 DAS with any of the herbicide reduced the dry weight of weeds similar to $2 \mathrm{HW}$ (30 and $60 \mathrm{DAS}$ ). Trifluralin at 1000 and $1250 \mathrm{~g} / \mathrm{ha}$ (PPI), pendimethalin $1250 \mathrm{~g} / \mathrm{ha}$ (PRE) reduced the dry weight of weeds to the extent of about $85 \%$ during two years. Trifluralin and pendimethalin each at $750 \mathrm{~g} / \mathrm{ha}$ $f b 1 \mathrm{HW}$ (45 DAS) being as effective as $2 \mathrm{HW}$ reduced the dry weight of weeds to the extent of about $90 \%$. These results are supported by Kumar et al. (2012).

\section{Effect on Crop}

Due to heavy weed infestation, the seed yield of mustard was minimum $(1396 \mathrm{~kg} / \mathrm{ha}$ in 2011-12 and $1486 \mathrm{~kg} / \mathrm{ha}$ in 2012-13) in untreated weedy check and it was maximum in weed free check (2006 kg/ha in 2011-12 and $2249 \mathrm{~kg} / \mathrm{ha}$ in 2012-13) during both years (Table 2). Among different herbicidal treatments, trifluralin 1000 and $1250 \mathrm{~g} / \mathrm{ha}$ (PPI), pendimethalin $1250 \mathrm{~g} / \mathrm{ha}$ (PRE), fluchloralin $750 \mathrm{~g} / \mathrm{ha} \mathrm{fb} 1 \mathrm{HW}$, trifluralin $750 \mathrm{~g} / \mathrm{ha}$ (PPI) $\mathrm{fb} 1$ $\mathrm{HW}$ and pendimethalin $750 \mathrm{~g} / \mathrm{ha} f b 1 \mathrm{HW}$ being at par with each other produced seed yield of mustard statistically similar to $2 \mathrm{HW}(30 \& 60$ DAS) and weed free check during both the years, and these treatments were superior to all other treatments. The seed yield and various yield attributes of irrigated mustard were increased when trifluralin (PPI) or pendimethalin (PPI \& PRE), each at $750 \mathrm{~g} / \mathrm{ha}$ integrated with $1 \mathrm{HW}$ at $45 \mathrm{DAS}$, and these were comparable to the treatment of 2HW (30 and 60 DAS) and also to the weed free conditions. Singh (2006) and Singh et al. (2009) also have proved that integration of herbicides with hand weeding is the most effective and economical method of weed management in rapeseed-mustard. In mustard, the PPI application of pendimethalin was superior over PRE application; however there were no significant differences in yield. Weeds growing throughout the crop season reduced the seeds yield of mustard to the extent of 30.4 and 33.9\% during 2011-12 and 201213 , respectively. In general, integrated method of weed management involving lower dose of herbicides $f b 1 \mathrm{HW}$ (45 DAS) proved more effective and remunerative. Similar results were attained earlier also by Chauhan et al. (1993) and Malik et al. (2012). Chauhan et al. (2005) 


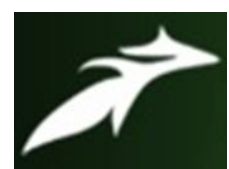

V. S. Hooda et al, International Journal of Advances in Agricultural Science and Technology, Vol.7 Issue.12, December-2020, pg. 98-103

ISSN: 2348-1358

Impact Factor: 6.057

NAAS Rating: 3.77

also observed that application of oxyfluorfen at $0.25 \mathrm{~kg} / \mathrm{ha}$ as pre-emergence, fluchloralin 1.0 $\mathrm{kg} / \mathrm{ha}$ as pre-plant application and two hand weedings (25 and 40 DAS) in Indian mustard drastically reduced weed density, weed biomass and increased the seed yield over other weed control treatments.

\section{Conclusion:}

Integration of one hand weeding at 45 DAS with pendimethalin (PPI \& PRE) or trifluralin (PPI), each at $750 \mathrm{~g} / \mathrm{ha}$, resulted into lower weed density and their dry weight along with higher mustard yield comparable to $2 \mathrm{HW}$ and weed free conditions.

\section{References}

[1]. Anonymous. 2019. Agricultural Statistics at a Glance 2019. Directorate of Economics and Statistics, Department of Agriculture, Cooperation and Farmers Welfare, Ministry of Agriculture and Farmers Welfare, Govt. of India, New Delhi

[2]. Anonymous. 2011. In: Annual Progress Report- 2011 of All India Co-ordinated Research Project on Rapeseed Mustard, DRMR, Bharatpur, Rajasthan, pp. 59-61.

[3]. Banga, R. S. and Yadav, A. 2001. Evaluation of herbicides against complex weed flora in Indian mustard. Haryana Journal of Agronomy, (17): 48-51.

[4]. Chauhan D. R., Balyan, R. S., Kadiyan, V. S. and Dhankar, R. S. 1993. Integrated weed management studies in raya (Brassica juncea L. Czern and Coss). Proc. International Symposium of Indian Society of Weed Science, 18-20 Nov. Hisar, India. $3: 114-116$.

[5]. Chauhan, Y.S., Bhargava, M.K. and Jain, V.K. 2005. Weed management in Indian mustard (Brassica juncea). Indian Journal of Agronomy, 50(2): 149-151.

[6]. Kumar, S., Kumar, A., Rana, S. S., Navell, C. and Angiras, N. N. 2012. Integrated weed management in mustard, Indian Journal of Weed Science, 44:139-143.

[7]. Malik, R.S., Yadav, A., Punia, S.S., Hooda, V.S. and Hasija, R.C. 2012. Efficacy of three dinitroaniline herbicides against weeds in raya. Environment and Ecology, 30 (3A): 787-789.

[8]. Punia, S.S., Shalini and Pahuja, S.S. 2006. Efficacy of oxadiargyl against weeds in Indian mustard (Brassica juncea L.). Haryana Journal of Agronomy, 22(1): 30-32.

[9]. Singh, R. 2006. Effect of cropping sequence, seed rate and weed management on weed growth and yield of Indian mustard in western Rajasthan. Indian Journal of Weed Science, 38(1\&2): 69-72.

[10].Singh, R. K., Singh, R. P. and Mukherjee, D. 2009. Effect of fertilizer placement and weed management practice on weed dynamics and yield of rainfed mustard (Brassica juncea L.). Environment and Ecology, 27(4B): 19321938. 


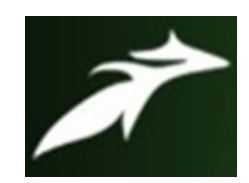

V. S. Hooda et al, International Journal of Advances in Agricultural Science and Technology,

Vol.7 Issue.12, December-2020, pg. 98-103

ISSN: 2348-1358

Impact Factor: 6.057

NAAS Rating: 3.77

Table 1: Effect of various weed management treatments on density of different weeds in mustard

\begin{tabular}{|c|c|c|c|c|c|c|c|c|c|c|}
\hline \multirow[t]{3}{*}{ Treatments } & \multicolumn{8}{|c|}{ Density of different weeds $\left(\mathrm{No} . / \mathrm{m}^{2}\right)$ at 70 DAS } & \multirow{2}{*}{\multicolumn{2}{|c|}{$\begin{array}{l}\text { Dry weight of different } \\
\text { weeds }\left(\mathrm{g} / \mathrm{m}^{2}\right) \text { at } 70 \text { DAs }\end{array}$}} \\
\hline & \multicolumn{2}{|c|}{ C. album } & \multicolumn{2}{|c|}{ C. arvensis } & \multicolumn{2}{|c|}{ M. indicus } & \multicolumn{2}{|c|}{ C. arvense } & & \\
\hline & $2011-12$ & $2012-13$ & 2011-12 & $2012-13$ & $2011-12$ & $2012-13$ & $2011-12$ & 2012-13 & $2011-12$ & $2012-13$ \\
\hline $\begin{array}{l}\text { Trifluralin } 750 \text { PPI + } 1 \\
\text { HW } 45 \text { DAS }\end{array}$ & 1.9 & 2.1 & 1.0 & 1.1 & 1.7 & 2.8 & 2.1 & 2.6 & 4.9 & 6.5 \\
\hline Trifluralin 1000 PPI & 3.1 & 4.0 & 3.2 & 4.1 & 6.2 & 8.3 & 8.3 & 10.1 & 18.5 & 23.6 \\
\hline Trifluralin 1250 PPI & 2.1 & 2.8 & 3.0 & 4.1 & 4.8 & 6.0 & 8.1 & 9.5 & 16.4 & 20.1 \\
\hline $\begin{array}{l}\text { Pendimethalin } 750 \text { PPI + } \\
1 \mathrm{HW} 45 \text { DAS }\end{array}$ & 1.6 & 1.7 & 1.0 & 0.0 & 2.8 & 2.1 & 2.1 & 2.7 & 4.8 & 5.8 \\
\hline Pendimethalin 1000 PPI & 2.7 & 3.4 & 2.5 & 4.1 & 4.4 & 5.3 & 8.5 & 10.5 & 21.4 & 27.7 \\
\hline Pendimethalin 1250 PPI & 2.0 & 1.5 & 2.1 & 3.5 & 3.4 & 4.3 & 7.1 & 9.8 & 18.7 & 24.1 \\
\hline $\begin{array}{l}\text { Pendimethalin } 750 \text { PRE + } \\
1 \mathrm{HW} 45 \text { DAS }\end{array}$ & 1.8 & 2.0 & 1.0 & 1.0 & 3.0 & 2.4 & 2.2 & 3.0 & 5.1 & 6.2 \\
\hline Pendimethalin 1000 PRE & 3.0 & 3.7 & 2.8 & 4.5 & 4.8 & 5.8 & 9.4 & 11.6 & 22.6 & 29.1 \\
\hline Pendimethalin $1250 \mathrm{PRE}$ & 2.2 & 1.7 & 2.3 & 3.9 & 3.7 & 4.7 & 7.8 & 10.8 & 19.6 & 25.9 \\
\hline $1 \mathrm{HW} 30 \mathrm{DAS}$ & 5.0 & 6.6 & 1.9 & 2.2 & 6.9 & 9.1 & 5.6 & 8.1 & 15.1 & 22.2 \\
\hline $2 \mathrm{HW} 30 \& 60 \mathrm{DAS}$ & 1.3 & 1.5 & 1.0 & 0.0 & 1.6 & 2.8 & 2.1 & 2.7 & 5.2 & 6.9 \\
\hline Weedy & 15.3 & 18.4 & 3.7 & 5.1 & 16.5 & 21.1 & 10.5 & 15.0 & 145.3 & 191.2 \\
\hline Weed free & 0.0 & 0.0 & 0.0 & 0.0 & 0.0 & 0.0 & 0.0 & 0.0 & 0.0 & 0.0 \\
\hline SEm \pm & 0.29 & 0.31 & 0.20 & 0.18 & 0.39 & 0.42 & 0.53 & 0.47 & 1.28 & 1.35 \\
\hline $\mathrm{CD}(5 \%)$ & 0.91 & 0.99 & 0.62 & 0.56 & 1.21 & 1.34 & 1.61 & 1.46 & 3.91 & 4.12 \\
\hline
\end{tabular}


V. S. Hooda et al, International Journal of Advances in Agricultural Science and Technology,

Vol.7 Issue.12, December-2020, pg. 98-103

ISSN: $2348-1358$

Impact Factor: 6.057

NAAS Rating: 3.77

Table 2: Effect of various weed management treatments on yield and yield attributes of mustard

\begin{tabular}{|c|c|c|c|c|c|c|c|c|}
\hline \multirow[t]{2}{*}{ Treatments } & \multicolumn{2}{|c|}{ No. of siliquae/ plant } & \multicolumn{2}{|c|}{ No. of seeds/ siliqua } & \multicolumn{2}{|c|}{ Test weight (g) } & \multicolumn{2}{|c|}{ Seed yield (kg/ha) } \\
\hline & 2011-12 & $2012-13$ & $2011-12$ & $2012-13$ & $2011-12$ & $2012-13$ & 2011-12 & $2012-13$ \\
\hline $\begin{array}{l}\text { Trifluralin } 750 \text { PPI + } 1 \text { HW } 45 \\
\text { DAS }\end{array}$ & 218 & 231 & 11.41 & 11.99 & 5.29 & 5.71 & 1886 & 2173 \\
\hline Trifluralin 1000 PPI & 207 & 219 & 11.21 & 11.65 & 5.19 & 5.58 & 1797 & 2059 \\
\hline Trifluralin 1250 PPI & 211 & 227 & 11.25 & 11.79 & 5.21 & 5.61 & 1829 & 2114 \\
\hline $\begin{array}{l}\text { Pendimethalin } 750 \mathrm{PPI}+1 \mathrm{HW} \\
45 \text { DAS }\end{array}$ & 220 & 231 & 11.31 & 11.90 & 5.24 & 5.66 & 1903 & 2144 \\
\hline Pendimethalin 1000 PPI & 201 & 209 & 11.23 & 11.51 & 5.20 & 5.47 & 1735 & 1943 \\
\hline Pendimethalin 1250 PPI & 208 & 225 & 11.19 & 11.64 & 5.20 & 5.52 & 1799 & 2099 \\
\hline $\begin{array}{l}\text { Pendimethalin } 750 \mathrm{PRE}+1 \mathrm{HW} \\
45 \mathrm{DAS}\end{array}$ & 214 & 232 & 11.32 & 12.04 & 5.23 & 5.73 & 1874 & 2166 \\
\hline Pendimethalin 1000 PRE & 196 & 207 & 11.29 & 11.57 & 5.24 & 5.49 & 1696 & 1924 \\
\hline Pendimethalin 1250 PRE & 212 & 224 & 11.19 & 11.59 & 5.21 & 5.51 & 1833 & 2076 \\
\hline $1 \mathrm{HW} 30 \mathrm{DAS}$ & 179 & 186 & 10.61 & 10.61 & 4.93 & 5.05 & 1533 & 1735 \\
\hline $2 \mathrm{HW} 30 \& 60$ DAS & 223 & 233 & 11.45 & 12.09 & 5.31 & 5.74 & 1926 & 2189 \\
\hline Weedy & 162 & 167 & 10.21 & 10.39 & 4.74 & 4.94 & 1396 & 1486 \\
\hline Weed free & 233 & 241 & 11.66 & 12.19 & 5.42 & 5.79 & 2006 & 2249 \\
\hline $\mathrm{SEm} \pm$ & 4.9 & 6.1 & 0.17 & 0.22 & 0.08 & 0.11 & 44.1 & 39.2 \\
\hline $\mathrm{CD}(5 \%)$ & 15.1 & 18.2 & 0.54 & 0.69 & 0.25 & 0.33 & 133.2 & 119.1 \\
\hline
\end{tabular}

